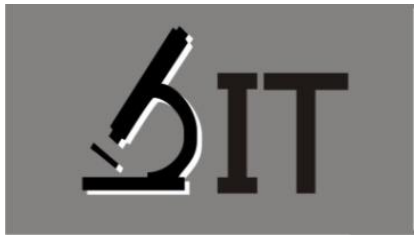

p-ISSN : 2597-8977

e-ISSN : 2597-8985

Rezki Eka Pratiwi*)

Jurusan Biologi Pascasarjana Universitas Negeri Makassar

Nurhayati B

Jurusan Biologi FMIPA

Universitas Negeri Makassar

Hartati

Jurusan Biologi FMIPA Universitas Negeri Makassar

*) Correspondence Author: rezkiekapratiwi50@gmail.com
JIT 4 (1) (2020) 72-80

JURNAL IPA TERPADU

http://ojs.unm.ac.id/index.php/ipaterpadu

\section{INOVASI PEMBELAJARAN IPA MELALUI MODEL ERCORe TERHADAP KETERAMPILAN METAKOGNITIF SISWA KELAS VIII SMP NEGERI 1 PAREPARE}

Abstrak: Penelitian ini bertujuan untuk mengetahui pengaruh model pembelajaran ERCoRe (Eliciting, Restructuring, Confirming, Reflecting) terhadap keterampilan metakognitif siswa kelas VIII SMP Negeri 1 Parepare. Penelitian ini merupakan penelitian eksperimen semu (quasi experiment) dengan desain penelitian pretest-posttest control group design. Populasi dalam penelitian ini adalah seluruh rombel kelas VIII semester ganjil SMP Negeri 1 Parepare tahun pelajaran 2019/2020. Sampel penelitian ini adalah kelas VIII.8 sebagai kelompok kontrol dan kelas VIII.9 sebagai kelompok eksperimen. Instrumen yang digunakan ialah tes keterampilan metakognitif dan tes hasil belajar. Data yang terkumpul dianalisis secara statistik deskriptif dan uji hipotesis secara inferensial melalui uji t. Hasil analisis statistik menunjukkan bahwa ada pengaruh model pembelajaran ERCoRe terhadap keterampilan metakognitif siswa.

Kata Kunci: Model Pembelajaran ERCoRe, Keterampilan Metakognitif.

Abstract: This aim of this research is to determine the influence of ERCoRe (Eliciting, Restructuring, Confirming, Reflecting) learning model on Metacognitive Skills of Class VIII students in Junior High School 1 Parepare. This research was quasi-experimental research with pretestposttest control group design. The population of research were all the students in VIII class for odd semester in Junior High School 1 Parepare 2019/2020 academic year. The sample of this research was the students in VIII.8 class as control class and VIII.9 class as experimental class. The instruments used were metacognitive skills tests and learning outcomes tests. The collected data were analyzed by descriptive statistics and inferential hypothesis testing through the $t$ test. The results of the statistical analysis show that there is an influence of the ERCoRe learning model on metacognitive skills.

Keyword: ERCoRe Learning, Metacognitive Skill. 


\section{PENDAHULUAN}

Pendidikan menjadi semakin penting untuk menjamin siswa memiliki keterampilan belajar, keterampilan untuk hidup, serta keterampilan menggunakan teknologi dan media informasi (Alismail \& McGuire, 2015). Salah satu keterampilan yang dapat diberdayakan di abad 21 adalah keterampilan metagokognitif. Keterampilan ini mengacu pada kemampuan seperti perencanaan, pemantauan diri, dan evaluasi diri dan akan mewakili prosedur dan strategi otentik yang digunakan untuk memantau dan mengendalikan kognisi seseorang. (Gracia, Cueli, Rodriguez, Krawes, \& Gonzales-Catro, 2015). Tanaka et al (2016) menyatakan bahwa guru dapat meningkatkan keterampilan metakognitif siswa dengan memberikan arahan dan menjelaskan kepada siswa bagaimana memikirkan apa yang dilakukan siswa. Siswa yang telah diajarkan keterampilan metakognitif hasil belajarnya lebih baik dan juga mampu mengembangkan bentukbentuk yang lebih tinggi dari pemikirannya (Kristiani, 2015).

Pada kenyataanya, pembelajaran IPA yang dilakukan selama ini hanya menekankan pada tujuan kognitif tanpa memperhatikan dimensi proses kognitif, khususnya ruang untuk metakognisi kurang dikembangkan. Kegiatan belajar tersebut membuat siswa cenderung hanya melatih siswa sekedar menghafal fakta, sehingga siswa pada umumnya tidak berdaya menghadapi masalah-masalah yang menuntut pemikiran dan pemecahan masalah. Fenomena tersebut didukung oleh penemuan peneliti dari beberapa sekolah di Indonesia misalnya pada SMP di kota Palu (Mamu, 2014), SMP kota Genteng (Putri et al, 2015), SMP di Pontianak (Hasri et al, 2016) mengungkap fakta bahwa keterampilan metakognitif siswa belum dikembangkan. Masalah tersebut juga dialami oleh siswa SMP Negeri 1 Parepare. Siswa terlihat sulit memahami materi yang diajarkan guru dan untuk mentransfernya pun sulit, sehingga pada saat ulangan harian, siswa bekerja keras untuk menghafal materi yang akan diujikan. Tujuan pembelajaran yang diberikan cenderung hanya pada jangka pendek saja. Siswa kurang didorong untuk meningkatkan kemampuan berpikirnya. Otak mereka distimulasi untuk mengingat dan menimbun berbagai informasi tanpa dituntut memahami informasi yang diingatnya. Menurut Nurhayati dan Hadis (2019) bahwa kemampuan siswa mengingat materi pelajaran sekitar 35-55\% jika mendengarkan dan melihat materi pelajaran. Kondisi tersebut dilatarbelakangi karena metakognisi merupakan hal yang baru bagi guru, sehingga guru belum mengetahui model pembelajaran yang cocok digunakan untuk melatih dan mengembangkan keterampilan metakognitif siswa. Guru juga belum mengetahui seperti apa alat evaluasi atau penilaian yang digunakan untuk mengukur keterampilan metakognitif.

Hasil dari pengembangan keterampilan metakognitif yang maksimal berkaitan dengan kualitas pengajaran. Guru dituntut untuk melakukan inovasi pembelajaran dengan bermacammacam interaksi di dalamnya. Inovasi pembelajaran yaitu proses belajar yang dirancang, dikembangkan dan dikelola secara kreatif, dinamis kearah yang lebih baik, untuk menciptakan suasana dan proses pembelajaran yang kondusif bagi siswa. Inovasi pembelajaran dapat dilakukan dengan mengubah aya belajar mengajar yang dulunya pasif harus diubah menjadi gaya belajar mengajar aktif. Menciptakan pembelajaran yang aktif tentunya diperlukan perencanaan yang baik, sehingga pendekatan, model maupun metode pembelajaran yang digunakan dapat mewujudkan kondisi pembelajaran yang efektif. Pendekatan konstruktivisme merupakan pendekatan yang menekankan pentingnya siswa membangun sendiri pengetahuan mereka lewat keterlibatan aktif dalam proses pembelajaran. Model pembelajaran eliciting, restructuring, confirming, dan reflecting (ERCoRe) merupakan salah satu model yang berorientasi pada pendekatan konstruktivistik. Model pembelajaran ini diharapkan mampu meningkatkan keterampilan metakognitif dan hasil belajar kognitif siswa.

Model pembelajaran ERCore yang dikembangkan oleh Nur Ismirawati (2015) yang dijabarkan melalui sintaks sebagai berikut, tahapan pertama yaitu Eliciting merupakan kata kerja yang artinya mendapatkan informasi. Pengetahuan Eliciting terdiri dari satu set teknik dan metode yang berusaha dilakukan untuk 
memperoleh pengetahuan dari ahli (Shadbolt, 2015). Kegiatan ini berupa pemberian aktivitas kepada siswa untuk mengamati bacaan/video/melakukan praktikum dan mengunjungi lokasi tertentu berdasarkan keterkaitan materi pembelajaran. Hasil kegiatan ini siswa diharapkan memiliki pengetahuan tambahan yang sebelumnya siswa telah memiliki pengetahuan awal. Tahap kedua yaitu restructuring, siswa diarahkan untuk mengklarifikasikan ide lama, membangun ide yang baru, menggunakan ide dalam banyak situasi. Kegiatan tersebut membantu siswa untuk belajar tidak dengan paksaan, tetapi mengajak siswa untuk menyusun kembali pengetahuan awal mereka secara mandiri maupun berkelompok melalui mind mapping. Kegiatan tersebut membantu siswa untuk belajar tidak dengan paksaan, tetapi mengajak siswa untuk menyusun kembali pengetahuan awal mereka secara mandiri maupun berkelompok melalui mind mapping. Tahap ketiga yaitu confirming, siswa melakukan presentasi depan kelas. Masing-masing kelompok mempresentasikan hasil diskusi mereka berupa mind mapping di depan kelas dan di konfirmasi oleh kelompok lain dan guru. Tahap keempat yaitu Reflecting terdapat kegiatan yang bertujuan melihat pengetahuan siswa setelah pembelajaran melalui pembuatan mind map secara mandiri. Reflecting berarti merefleksi informasi yang telah didapatkan. Kegiatan merefleksi dilakukan dengan membuat mind map secara mandiri.

Penggunaan model ERCoRe dalam proses pembelajaran, melatih siswa melakukan berbagai macam aktivitas, yaitu membaca, membuat mind map, diskusi, dan merefleksi pengetahuannya. Tujuan utama dalam model pembelajaran ERCoRe adalah dengan memberikan kesempatan kepada siswa untuk mengkonstruk pengetahuan mereka dan melatih siswa untuk mengembangkan keterampilan metakognitif (Ismirawati et al, 2015). Berdasarkan uraian tersebut, maka peneliti mengadakan penelitian dengan judul "pengaruh model pembelajaran ERCoRe terhadap keterampilan metakognitif siswa kelas VIII SMP Negeri 1 Parepare".

\section{METODE}

Penelitian ini merupakan penelitian eksperimen semu. Desain penelitian yang digunakan adalah pretest-posttest control group design. Penelitian ini dilaksanakan pada semester ganjil tahun ajaran 2019/2020, di SMP Negeri 1 Parepare. Populasi pada penelitian ini adalah seluruh siswa kelas VIII SMP Negeri 1 Parepare. Teknik sampling yang digunakan adalah random sampling. Sampel penelitian ini adalah kela VIII.8 sebagai kelompok control dan VIII.9 sebagai kelompok eksperimen. Alokasi waktu untuk pembelajaran 4 kali pertemuan dan 2 kali pertemuan untuk melaksanakan evaluasi (pretest dan posttest). Materi yang diajarkan adalah sistem pencernaan manusia.

Penggumpulan data dilakukan dengan cara tes untuk mendapatkan data tentang keterampilan metakognitif. Data yang diperoleh dalam penelitian ini selanjutnya dianalisis menggunakan dua jenis statistik, yaitu statistic deskriptif dan inferensial. Analisis statistik deskriptif digunakan mendeskripsikan karakteristik keterampilan metakognitif yang diperoleh siswa kelas VIII SMP Negeri 1 Parepare, baik pada kelompok eksperimen maupun kelompok kontrol. Skor perolehan siswa kemudian dimasukkan ke rumus keterampilan metakognitif menurut Corebima (2008) berikut.

$$
\frac{y 1+2 x}{3}=y^{2}
$$

Keterangan:

$\mathrm{y} 1$ = skor pemahaman konsep

y2 = skor gabungan antara pemahaman konsep dan keterampilan metakognitif

$\mathrm{x}=$ skor keterampilan metakognitif 
selanjutnya, kriteria yang digunakan untuk menentukan kategori keterampilan metakognitif siswa dapat dilihat pada Tabel 1 berikut.

Tabel 1. Pedoman Pengkategorian Keterampilan Metakognitif

\begin{tabular}{cc}
\hline Interval Skor & Kategori \\
\hline$M+1,5$ SD $<X$ & Berkembang sangat baik \\
$M+0,5$ SD $<\leq M+1,5$ SD & Berkembang baik \\
$M-0,5 S D<X \leq M+0,5$ SD & Mulai berkembang \\
$M-1,5 S D<X \leq M-0,5$ SD & Belum berkembang \\
$X \leq M-1,5$ SD & Sangat beresiko \\
\hline
\end{tabular}

Peningkatan keterampilan metakognitif siswa dianalisis menggunakan N-Gain. Gain adalah selisih antara nilai postest dan pretest. Rumus normal N-Gain menurut Hake (2002) sebagai berikut.

$$
N-\text { gain }=\frac{\text { Spost }- \text { Spre }}{\text { Smaks }- \text { Spre }}
$$

Analisis statistik inferensial digunakan untuk membuktikan kebenaran hipotesis penelitian yang telah diajukan menggunakan rumus uji-t, yaitu uji perbedaan dua rata-rata dengan hipotesis dua pihak, dengan kriteria pengujian terima $\mathrm{H} 1$ apabila thitung $>$ ttabel, dimana taraf signifikan $a=0,05$ dengan $\mathrm{dk}=\mathrm{n} 1+\mathrm{n} 2-2$.

\section{HASIL DAN PEMBAHASAN}

\section{Hasil}

\section{a. Hasil Analisis Deskriptif}

1) Keterampilan metakognitif siswa melalui model pembelajaran ERCoRe

Hasil analisis statistik deskriptif menunjukkan bahwa skor keterampilan metakognitif siswa melalui model pembelajaran ERCoRe berada antara 55 sampai 94 dengan rata-rata pretest dan posttest keterampilan metakognitif dari 32 siswa yaitu 68,34 menjadi 84,84 . Keseluruhan nilai keterampilan metakognitif yang diperoleh siswa pada kelas eksperimen melalui model pembelajaran ERCoRe di kelompokkan pada Tabel 1 sebagai berikut.

Tabel 2. Distribusi Frekuensi dan Persentase Keterampilan Metakognitif Siswa melalui Model Pembelajaran ERCoRe

\begin{tabular}{cccccc}
\hline \multirow{2}{*}{ Interval } & \multirow{2}{*}{ Kategori } & \multicolumn{2}{c}{ Frekuensi } & \multicolumn{2}{c}{ Persentase \% } \\
& & Pretest & Posttest & Pretest & Posttest \\
\hline $92 \leq X \leq 100$ & Berkembang sangat baik & 0 & 7 & 0 & 21,87 \\
$80 \leq X<92$ & Berkembang baik & 0 & 18 & 0 & 56,25 \\
$70 \leq X<80$ & Mulai berkembang & 13 & 7 & 40,63 & 21,87 \\
$60 \leq X<70$ & Belum berkembang & 14 & 0 & 43,75 & 0 \\
$X<60$ & Sangat beresiko & 5 & 0 & 15,63 & 0 \\
\hline & Jumlah & $\mathbf{3 2}$ & $\mathbf{3 2}$ & $\mathbf{1 0 0}$ & $\mathbf{1 0 0}$ \\
\hline
\end{tabular}


Data mengenai distribusi dan frekuensi perolehan pretest dan posttest siswa melalui model pembelajaran ERCoRe dapat dilihat dari peningkatan keterampilan metakognitif siswa dengan persamaan Normalitas Gain pada Tabel 2 sebagai berikut.

Tabel 3. Peningkatan Keterampilan Metakognitif Siswa melalui Model Pembelajaran ERCoRe

\begin{tabular}{cccc}
\hline Interval & Kategori & Frekuensi & Persentase (\%) \\
\hline $\mathrm{g}>0,70$ & Tinggi & 7 & 21,88 \\
$0,30 \leq \mathrm{g} \leq 0,70$ & Sedang & 22 & 68,75 \\
$\mathrm{~g}<0,30$ & Rendah & 3 & 9,37 \\
\hline Jumlah & & $\mathbf{3 2}$ & $\mathbf{1 0 0}$ \\
\hline
\end{tabular}

2) Keterampilan metakognitif siswa melalui model pembelajaran Direct Instruction

Hasil analisis statistik deskriptif menunjukkan bahwa skor keterampilan metakognitif siswa melalui model pembelajaran Direct Instruction berada antara 51 sampai 94 dengan rata-rata pretest dan posttest keterampilan metakognitif dari 32 siswa yaitu 66,97 menjadi 79,00. Keseluruhan nilai keterampilan metakognitif yang diperoleh siswa pada kelas eksperimen melalui model pembelajaran Direct Instruction di kelompokkan pada Tabel 3 sebagai berikut.

Tabel 4. Distribusi Frekuensi dan Persentase Keterampilan Metakognitif Siswa melalui Model Pembelajaran Direct Instruction

\begin{tabular}{cccccc}
\hline \multirow{2}{*}{ Interval } & \multirow{2}{*}{ Kategori } & \multicolumn{2}{c}{ Frekuensi } & \multicolumn{2}{c}{ Persentase $\%$} \\
& & Pretest & Posttest & Pretest & Posttest \\
\hline $92 \leq X \leq 100$ & Berkembang sangat baik & 0 & 2 & 0 & 6,25 \\
$80 \leq X<92$ & Berkembang baik & 0 & 12 & 0 & 37,5 \\
$70 \leq X<80$ & Mulai berkembang & 10 & 15 & 31,25 & 46,87 \\
$60 \leq X<70$ & Belum berkembang & 16 & 3 & 50 & 9,38 \\
$X<60$ & Sangat beresiko & 6 & 0 & 18,75 & 0 \\
\hline & Jumlah & 32 & $\mathbf{3 2}$ & $\mathbf{1 0 0}$ & $\mathbf{1 0 0}$ \\
\hline
\end{tabular}

Data mengenai distribusi dan frekuensi perolehan pretest dan posttest siswa melalui model pembelajaran Direct Instruction dapat dilihat dari peningkatan keterampilan metakognitif siswa dengan persamaan Normalitas Gain pada Tabel 4 sebagai berikut.

Tabel 5. Peningkatan Keterampilan Metakognitif Siswa melalui Model Pembelajaran Direct Instruction

\begin{tabular}{cccc}
\hline Interval & Kategori & Frekuensi & Persentase (\%) \\
\hline $\mathrm{g}>0,70$ & Tinggi & 3 & 9,37 \\
$0,30 \leq \mathrm{g} \leq 0,70$ & Sedang & 17 & 53,13 \\
$\mathrm{~g}<0,30$ & Rendah & 12 & 37,50 \\
\hline Jumlah & & $\mathbf{3 2}$ & $\mathbf{1 0 0}$ \\
\hline
\end{tabular}

\section{b. Hasil Analisis Inferensial}

Analisis inferensial dilakukan dengan menggunakan uji-t. Berdasarkan hasil analisis diperoleh nilai sig.hitung $(0,001)<$ sig.tabel $(\alpha)(0,05)$, maka hipotesis $\mathrm{H}_{0}$ ditolak dan $\mathrm{H}_{1}$ diterima yang berarti bahwa model pembelajaran ERCoRe berpengaruh terhadap keterampilan metakognitif siswa. 


\section{Pembahasan}

Berdasarkan analisis uji hipotesis dengan menggunakan uji-t dua pihak diperoleh informasi bahwa ada perbedaan keterampilan metakognitif yang signifikan antara siswa yang diajar melalui model pembelajaran ERCoRe dan Direct Instruction yang artinya terdapat pengaruh model pembelajaran ERCoRe terhadap keterampilan metakognitif siswa. Hal ini sejalan dengan hasil penelitian Ismirawati (2018) yang menemukan adanya pengaruh model pembelajaran ERCoRe terhadap keterampilan metakognitif.

Berkembangnya keterampilan metakognitif siswa tidak terlepas dari sintaks model pembelajaran ERCoRe. Informasi penting dari model pembelajaran ERCoRe yaitu siswa dianggap telah memiliki pengetahuan awal, sehingga sintaks pertama yang diberikan adalah melalui eliciting yang berarti mengumpulkan data/fakta melalui kegiatan membaca. Pengetahuan awal memberikan manfaat dalam pemahaman membaca, efek yang didapatkan antara lain; membantu siswa untuk membuat kesimpulan tentang yang dibaca, berfokus pada informasi yang penting dalam teks tentang topic yang diminati dan akhirnya memberikan sebuah rangsangan untuk mengingat kembali informasi tersebut setelah membaca teksnya.

Berkembangnya keterampilan metakognitif siswa yang diajar melalui model pembelajaran ERCoRe juga tidak terlepas dari penugasan membuat mind map secara berkelompok. Siswa yang membuat mind map, akan lebih mudah memahami materi. Hal tersebut sejalan dengan pendapat Edmondson \& Smith (1996) bahwa membuat mind mapping pada konsepnya merupakan strategi metakognitif karena menghubungkan konsep dalam struktur pemahaman.

Pada pembelajaran ERCoRe, siswa juga dituntut untuk terlibat aktif dalam proses pembelajaran. Siswa secara kooperatif mengkonfirmasi konsep yang mereka dapatkan dari kegiatan membaca dan membuat mind mapping. Menurut Slavin (2010) dalam pembelajaran kooperatif siswa belajar bersama saling menyumbang pikiran dan tanggung jawaba terhadap pencapaian hasl belajar, baik secara individual ataupun kelompok. Pada tahap ini siswa mempresentasikan hasil mind mapnya kemudian siswa lain memberi pertanyaan jika merasa kurang paham. Kegiatan tersebut membantu siswa untuk memberdayakan keterampilan metakognitifnya. Mengetahui apa yang tidak mereka ketahui, sehingga memberikan pertanyaan dan meningkatkan pemahaman tentang materi pelajaran. Hal ini sejalan dengan pendapat Corebima (2006) yang menyatakan bahwa dengan pembelajaran kooperatif dapat membantu siswa untuk memberdayakan keterampilan metakognitifnya. Beberapa penelitian pun juga mengungkap bahwa dengan pembelajaran kooperatif efektif meningkatkan keterampilan metakognitif siswa (Yuwono, 2014; dan Setiawan \& Susilo, 2015).

Model pembelajaran ERCoRe juga memberi peluang bagi siswa untuk belajar mandiri. Tahap tersebut disebut reflecting yang berarti refleksi informasi yang telah didapatkan. Kegiatan refleksi yang dilakukan dengan membuat mind mapp secara mandiri di rumah. Menurut Wiliams (2012) manfaat dari membuat mind map adalah membuat siswa menjadi lebih paham tentang apa yang telah dipelajari dan juga bagaimana mereka berpikir (metakognitif). Memberikan kegiatan tersebut memungkinkan siswa untuk menunjukkan apa yang mereka tahu, berpikir tentang hal yang cukup berguna untuk proses kognitif dan menemukan pendekatan yang paling tepat untuk belajar (Cabrera-Solano et al, 2019).

Metakognisi yang terus berkembang dari waktu ke waktu merupakan sesuatu yang disadari dan sebagian tidak disadari oleh setiap individu. Setiap individu memiliki cara yang berbeda-beda untuk mengembangkan rekognisi sehingga ada individu yang memiliki tingkat kesadaran metakognitif yang tinggi dan ada pula yang memiliki tingkat kesadaran metakognitif yang rendah (Ramadhanti, 2019). 


\section{KESIMPULAN}

Berdasarkan tujuan, hasil penelitian, dan pembahasan yang telah diuraikan maka dapat disimpulkan bahwa: (1) peningkatan keterampilan metakognitif siswa melalui model pembelajaran ERCoRe berada pada kategori sedang, (2) Peningkatan keterampilan metakognitif siswa melalui model pembelajaran Direct Instruction berada pada kategori sedang.

\section{DAFTAR PUSTAKA}

Alismail, H.A., \& McGuire, P. (2015). $21^{\text {St }}$ Century Standards and Curriculum: Current Research and Practice. Journal of Education and Practice. 6(6):150-154.

Cabrera-Solano, P., Gonzalez-Torres, P., Solano, L., \& Castillo-Cuesta L. (2019). Using Visual Vocabulary App as a Metacognitive Strategy in EFL Learning: A Case of Pre-Service Teachers. International Journal of Learning, Teaching and Educational Research. 18(12), pp. 302-315.

Corebima, A.D. (2006). Pembelajaran Biologi Yang Memberdayakan Kemampuan Berpikir Siswa. Makalah disajikan dalam Pelatihan Strategi Metakognitif pada Pembelajaran Biologi untuk Guru-guru Biologi SMA, Lembaga Pengabdian Kepada Masyarakat (LPKM) UNPAR, Palangkaraya, 23 Agustus 2006.

Corebima, A.D. (2008). Metacognitive Skill Measurement Integrated in Achievement Test. State University of Malang

Edmondson, K. M., \& Smith, D.F. (1996). Concept Mapping to Facilitate Veterinary Students' Understanding of Fluid Disorders. Paper presented at the annual meeting of the American Educational Research Association. New York.

Gracia, T., Cueli, M., Rodriguez, C., Krawes, J., \& Gonzales-Castro, P. (2015). Metacognitive Knowledge and Skills in Students with Deep Approach to Learnig. Evidence from Mathematical Problem Solving. Revista de Psicodidactica. 20(2), 209-226.

Hake, R.R. (2002). Relationship of Individual Student Normalized Learning Gains in Mechanics with Gender, High-School Physics, and Pretest Scores on Mathematics and Spatial Visualization. Physics Education Research Conference. 8(1), 1-14.

Hasri, Y., Yusmin, E. \& Nursangaji, A. (2016). Keterampilan Metakognisi Siswa dalam Problem Solving Berbentuk Open Start Berdasarkan Gaya Kognitif di SMP. Jurnal Pendidikan \& Pembelajaran Khatulistwa. 5(5).

Ismirawati, N., Corebima, A.D., Zubaidah, S. \& Syamsuri, I. (2015). Prototype Model Pembelajaran ERCoRe untuk Memberdayakan Keterampilan Metakognisi. Makalah diseminarkan pada Seminar Nasional UNS. Solo: UNS

Ismirawati, N. (2018). Pengaruh Model Pembelajaran Eliciting, Restructuring, Confirming, Reflecting (Ercore) pada Kemampuan Akademik Berbeda Terhadap Keterampilan Metakognitif, Hasil Belajar Biologi, dan Retensi Siswa Kelas X SMA Negeri Kabupaten Pangkep. Disertasi. Tidak diterbitkan. Malang: Program Pascasarjana. 
Kristiani, N. (2015). Hubungan Keterampilan Metakognitif dan Hasil Belajar Kognitif Siswa pada Pembelajaran Saintifik dalam Mata Pelajaran Biologi SMA Kurikulum 2013. Prosiding Seminar Nasional XII Pendidikan Biologi FKIP UNS 2015. 513-518. Solo: UNS.

Mamu, H.D. (2014). Profil Keterampilan Berpikir Kritis dan Metakognisi Siswa dalam Pembelajaran IPA Biologi di SMP. Kreatif, vol 17(3).

Nurhayati, B., \& Hadis, A. (2019). Strategi Belajar Mengajar Edisi Revisi. Makassar: Badan Penerbit UNM.

Putri, R.S., Susanto \& Kurniati, D. (2015). Analisis Keterampilan Metakognitif Siswa dalam Menyelesaikan Masalah Matematika Berbasis Polya Subpokok Bahasan Garis \& Sudut Kelas VII-C di SMPN 1 Genteng Bayuwangi. SRA Education. 7(1).

Ramadhanti, D. (2019). Students' Metacognitive Weaknesses in Academic Writing: A Preliminary Research. International Journal of Emerging Technologies in Learning. 14(11)

Setiawan, D., \& Susilo, H. 2015. Peningkatan Keterampilan Metakognitif Mahasiswa Program Studi Biologi Melalui Penerapan Jurnal Belajar Dengan Strategi Jigsaw Dipadu Pbl Berbasis Lesson Study Pada Matakuliah Biologi Umum. Prosiding Seminar Nasional Pendidikan Biologi 2015.

Shadbolt, N.R. \& Smart, P.R. (2015). Knowledge Elicitation. In J. R. Wilson \& S. Sharples (Eds.), Evaluation of Human Work (4th ed.). CRC Press, Boca Raton, Florida, USA.

Shoebottom, Paul. 2007. The Importance of Reading. Diakses 25 Januari 2020 dari http://www.familyresource.com/parenting/childdevelopment/why-reading-issoimportantfor children,).

Slavin, R.E. (2010). Cooperative Learning: Teori Riset dan Praktik. Terjamahan Narrolita Yuson. Bantung: Nusa Media

Sudijono, A. (2016). Pengantar Evaluasi Pendidikan. Jakarta: Rajawali Pers.

Tanaka, K., Dam, C. H., Kobayasih, S., Hashimoto, T.,\& Ikeda, M. (2016). Learning how to learn throygh experiental leaning promoting metacognitive skills to improve knowledge cocreation ability. International Conference on Knowledge Management, Viebba Austria, Oktober 2016. 146-156.

Wiliams, K. (2012). Peta Pemikiran (Thinking Maps). Edisi bahasa Indonesia. Jakarta: PT Indeks.

Yuwono, C.S.M. (2014). Peningkatan Keterampilan Metakognisi Siswa dengan Pembelajaran Jigsaw-Modifikasi. Jurnal Santiaji Pendidikan. 4 (1) 


\section{Rezki Eka Pratiwi}

Mahasiswa Program Pascasarjana Universitas Negeri Makassar, dapat dihubungi melalui email: rezkiekapratiwi50@gmail.com .

\section{Nurhayati B}

Dosen Jurusan Biologi, Fakultas Matematika dan Ilmu Pengetahuan Alam Universitas Negeri Makassar. Jl. Daeng Tata Raya, Makassar, dapat dihubungi melalui email: nurhayati.b@unm.ac.id.

\section{Hartati}

Dosen Jurusan Biologi, Fakultas Matematika dan Ilmu Pengetahuan Alam Universitas Negeri Makassar. Jl. Daeng Tata Raya, Makassar, dapat dihubungi melalui email: hartati@unm.ac.id. 